International Journal of Economics and Business Administration

Volume VI, Issue 2, 2018

pp. $56-67$

\title{
The Effect of Tax Structure in Economic Growth
}

\author{
B. Gashi ${ }^{1}$, G. Asllani ${ }^{2}$, L. Boqolli ${ }^{3}$
}

\begin{abstract}
:
The main goal of this paper is to analyse the effect of the tax structure in the economic growth of Kosovo in the period 2007-2015. The study intends to evaluate the impact of specific types of taxes on economic growth.
\end{abstract}

The methodology is based on comparative analysis of data using primary and secondary sources. Through the econometric model and linear regression analysis, the research hypotheses have been tested with STATA application/software to calculate the impact of tax structure in economic growth.

The econometric model includes several independent variables (types of taxes), and the dependent variable GDP. Based on data obtained through the log-log model, the results show the impact of special taxes such as Pt, It, VAT, Wt, Ibt, Tdr.., Ct on GDP.

The results show that most of the taxes have a positive impact on GDP growth; it is also shown that not all taxes have the same impact on economic growth.

In the econometric analysis the coefficient of $R 2=0,999$ reflects the high degree of determination with $99.9 \%$ forecasting accuracy.

Keywords: Tax structure, taxation, GDP, economic growth, budget revenues.

\footnotetext{
${ }^{1}$ University "Haxhi Zeka”, Peja, Kosovo, e-mail: burimgashi8@hotmail.com

${ }^{2}$ Corrospoding author, Professor at University "Haxhi Zeka", Peja, Kosovo, e-mail: gani.asllani@unhz.eu

${ }^{3}$ University “Haxhi Zeka”, Peja, Kosovo,e-mail: liridonaboqolli@gmail.com
} 


\section{Intruduction}

The Republic of Kosovo has built and continues to build a simple tax system, by the application of a low tax rates scheme and an extended tax basis. The fiscal system is relatively new, a system that is based on direct and indirect taxes. The capacity building has started since 1999 with the Regulation on customs, then in 2001 begin to apply and other taxes as: prejudice tax (May 2000), VAT (May 2001), income tax (April 2002), property tax (June 2003), corporation tax (December 2004) on the road tax (March 2005), royalties' tax and steadily the application of other non-tax revenues. Since January 2005, tax policies begun with the initial tax amendments and with the application of new taxes such as Corporate Income Tax (CIT) as well as Personal Income Tax (PIT) and this continued until the end of 2008. In January 2009 a new law started to apply, with deduction in tax rates in Kosovo, also imposing the tax rates on dividends, interest, rent, gambling, capital gains, sale of intangible property, etc. In September 2017 the reform of the VAT legislation was reformulated.

Currently, the tax system in Kosovo is quite simple and harmonized. However, tax system and tax policy in Kosovo must be reformed in many other segments. Budget revenues consist mainly of tax revenues, which have a share of about 83.5 percent of total budget revenues. Out of the total tax revenues, 86.0 percent are indirect tax revenues, while only 14.0 percent are direct tax revenues having a crucial impact on the functioning of the state to meet public needs and economic development.

\section{Literature review}

The experience of many countries suggests that the impact of increasing economic taxes affects the fiscal policy making the economists to prompt for further research that leads to the question of whether there is a positive or negative impact on GDP. With the review of the literature, we see that many authors have studied and analyzed the relationship between taxation and economic growth and the results have shown slightly negative impact (Ferede and Dahlby, 2012; Nechaev and Antipina, 2016).

Many authors have also studied the issue of taxation from different perspectives. The isuess of productivity of government spending and its impact on the economic growth associated with funding from different types of taxes. Barro (1990) analyzing the ratio between the real expenditure of government consumption to real GDP has found a significant negative correlation between these variables with the economic growth. Economic growth is positively affected by productive and negative costs, but the first has a greater impact (Buturac, 2014).

The direct taxes negatively impact GDP growth rate per capita, and a strong negative impact on the accumulation of physical capital (Romero-Avila and Strauch, 2008). The tax structure based on selective taxation such as consumption, personal income 
tax, and property tax are more supportive of economic growth (Stoilova, 2017). The reduction of tax rate on tax in consumtion for basic products and an increase in tax rate on luxury products has a positive effect on the growth of GDP (Asllani and Statovci, 2018; Gasteratos et al., 2016). The corporate income taxes have the most negative impact on GDP per capita, while real estate taxes and especially reuse tax on real estate has a more positive effect on growth, as well as taxes in consumption and taxes on personal income (Arnold, 2008). High corporate taxes discourage potential investors from realizing investments in the given country (Beker, 2009). From the current researches both theoretically and empirically it is concluded that there is no optimal tax system because its construction depends on many quantitative and qualitative factors and varies from state to state.

Corporate taxes reduce the return on invested capital and the capital structure or age of a company (Daniel and Jefferey 2013). The existence of the negative link between corporate tax and foreign direct investment (FDI) is argued by Schraztenstaller and Kohler (2015), while the low tax rate represents the stimulating factor influx of FDI (Bre-Bler, 2012). Changes in both the level of income and the structure of the tax system can affect economic activity, but not all tax changes have the same, even positive, long-term effects (Gale and Samwick, 2014). High taxes reduce consumer income and limit their economic freedom in the short run but may also reduce economic efficiency and welfare in the long-term. If expenditures were cut short this would immediately affect categories that benefit directly from government programmes (Vito, 1990). Taxes, as the main and most important tool for collecting public revenues are presented in a variety of forms (Rimmler et al., 2017). Thus, according to this criterion, taxes paid on income generation represent the group of direct taxes, whereas those realized at the time of income spending are included in the group of indirect taxes (Jelcić, 1997).

Examining the impact of taxes on economic growth makes it possible to observe that the level of capital and intermediate goods tax has a significant effect on economic growth; countries with lower taxes grow faster than those applying high taxes (Gerson, 1998). In an analysis of the relationship between taxes and the rate of economic growth among 23 OECD countries for the period 1965-1990, not relying on any argument that there is any correlation between the tax rate and economic growth, it was found that taxes have a negative effect on economic growth (Widmalm, 1999). The author concludes by means of econometric analysis that progressive taxation results in a higher negative effect on real GDP.

Given the size of the parameter, government revenues affect economic growth more than government spending. Fiscal policy measures can counter and improve the short-term difficulties driven by damaging trends in the economy (Genser, 2006). They can also eliminate the causes of these trends and establish stability with measures of stabilization policy. In addition to short-term flows, fiscal policy can be oriented to the long-term growth of GDP and per capita income, respectively. In this case, this relates to the rate of economic growth (Gallagher and Babič, 2005). 


\section{Data and methodology}

The purpose of this research is to analyse the effect of tax structure in the economic growth of Kosovo. Through the interconnection of variables, it is attempted to understand and identify the impact of specific taxes on economic growth. To this end, an econometric model was used to analyse the relationship between economic variables such as GDP as the dependent variable and several taxes as the independent variables. Among them the presumptive personal tax $(\mathrm{Pt})$, taxes on income (It), Value Added Tax (VAT), withholding tax (Wt), tax on individual businesses (Ibt), tax on interest, on dividends, on rent, on the win of the lottery or other gambling games (Tdr), the corporate tax, etc.

\section{Research Methodology}

For the purpose of developing this work, comparative analysis methodology was adopted, using primary data and other secondary sources. We used the econometric model by collecting data and converting them in natural logarithm using the LOGLOG model. The research question is will fiscal policy have an impact on economic development and growth or will have a negative impact on GDP? By raising the research hypotheses, we examine the positive or negative effect of the structure of taxes in economic growth by setting them as:

$H_{0}=$ Taxes have negative effects on the economic growth affecting GDP negatively (decline).

$H_{1}=$ Taxes have positive effects on economic growth, affecting GDP positively (growth).

\subsection{Tax Revenues collected from Tax Administration}

The Kosovo Tax Administration from the beginning of its operation achieved significant results collecting revenues effectively. The progress achieved refers to the provision of voluntary relief facilities, equal treatment of all taxpayers, and successful implementation of revenue collection planning. The success achieved refers to the provision of professional, transparent and effective services and through the fair and uniform implementation of tax laws, the modernization of the large taxpayer unit, the extension of functions at the call centre, the development of online tax declarations, and increasing the capacities in the risk management unit and the tax investigation unit. The Tax Administration of Kosovo has realized higher revenues from year to year by increasing voluntary compliance with tax obligations, as well as reducing the cost to taxpayers in performing their tax obligations.

The following tables represent revenues collected from Tax Administration for years, revenues from different types of taxes and their impact on overall revenues. 
Based on these tables and the econometric approach regarding GDP correlation over the years, their positive or negative effect on economic growth has been tested.

Table 1: Structure of revenues (2007-2015) in million euros

\begin{tabular}{|l|l|l|l|l|l|l|l|l|l|}
\hline Tax & $\mathbf{2 0 0 7}$ & $\mathbf{2 0 0 8}$ & $\mathbf{2 0 0 9}$ & $\mathbf{2 0 1 0}$ & $\mathbf{2 0 1 1}$ & $\mathbf{2 0 1 2}$ & $\mathbf{2 0 1 3}$ & $\mathbf{2 0 1 4}$ & $\mathbf{2 0 1 5}$ \\
\hline $\begin{array}{l}\text { Personal } \\
\text { tax }\end{array}$ & 1,269 & 1,002 & 3,007 & 2,307 & 1,841 & 1,203 & 1,299 & 1,338 & 1,236 \\
\hline Profit Tax & 2,919 & 2,646 & 8,479 & 7,412 & 5,188 & 2,263 & 2,443 & 2,516 & 2,592 \\
\hline VAT & 59,392 & 60,771 & 85,807 & 103,216 & 117,323 & 132,641 & 143,251 & 147,547 & $\begin{array}{l}150,29 \\
7\end{array}$ \\
\hline $\begin{array}{l}\text { Withholdi } \\
\text { ng Tax }\end{array}$ & 35,257 & 41,649 & 38,162 & 41,704 & 46,708 & 50,913 & 54,896 & 56,635 & 61,386 \\
\hline $\begin{array}{l}\text { Tax on } \\
\text { individual } \\
\text { Businesse } \\
\text { s }\end{array}$ & 18,358 & 19,401 & 20,694 & 22,611 & 25,325 & 27,607 & 29,816 & 30,711 & 31,632 \\
\hline $\begin{array}{l}\text { Tax in } \\
\text { interes, } \\
\text { dividend } \\
\ldots\end{array}$ & 10,251 & 14,168 & 14,868 & 1,196 & 1,382 & 1,618 & 1,747 & 1,801 & 1,854 \\
\hline $\begin{array}{l}\text { Corporate } \\
\text { Tax }\end{array}$ & 47,798 & 56,067 & 35,452 & 46,655 & 54,335 & 58,561 & 63,245 & 65,142 & 65,865 \\
\hline
\end{tabular}

Source: TAK-Annual reports for 2007-2015.

In the structure of revenues by different types of taxes yearly, the largest share has been the VAT amounting to more than $46.1 \%$, the corporate tax with $22.3 \%$, the tax withholding tax with $18.2 \%$, the individual business tax with $10.8 \%$, the profit tax with $3.5 \%$ and the tax on interest, dividends, lottery winnings and gambling with $0.1 \%$, and the preliminary tax with $0.05 \%$.

\section{Empirical analysis on testing the tax effects on GDP}

Following the specification of the log-log model and the valuation method, the data were analysed, calculated and the results interpreted accordingly. Finally, the validity of the hypotheses defined in the research are verified. Through the simple linear regression method and through the log-log method application, the effects of the tax on GDP are tested. Therefore, the specification of the seven-dimensional linear regression model is as follows:

$Y=B 1+B 2+B 3+B 4+B 5+B 6+B 7+B 8+U i$

Or $Y(G D P)=+B 1(P t)+B 2(I t)+B 3(V A T)+B 4(W t)+B 5(I b t)+B 6(T d r)+B 7(C t)+B 8+$ $U I$

Through the simple linear regression method and via the log-log method (OLS) application, the effects of several taxes on GDP of the Republic of Kosovo in the period of 2007-2015 were tested. Therefore, the specification of the linear linear regression model is as follows: 
$\mathrm{Y}$ - represents the dependent variable, in our case the dependent variable is GDP (Gross Domestic Product);

$\mathrm{X}$ - represents the independent variables: B2, B3, B4, B5, B6, B7, B8. Where B1 is the constant parameter, while B2, B3, B4, B5, B6, B7, B8 are the independent variables while ui is a stochastic or eror term variable, which contains all the factors or variables that are not foreseen in the model and is a random and unobserved variable that captures positive and negative values.

\subsection{The method of Ordinary Least Squares (OLS)}

Using this method is because is one of the useful methods for calculating the regression of eight variables in the researched case. The model has simplicity derived because of the normality of the error term (ui) or better to say the error term is normaly distributed. In other words, the model analyzed does not clarify all variables that can affect the independent variable, so observations are not correlated with each other. This model has a more efficient estimate than the other example model of maximum likelyhood (ML) so all collected data will be evaluated via (OLS) in our empirical analysis:

$\mathrm{Y}-$ or $\mathrm{B}_{1} \log$ on GDP;

$\mathrm{B}_{2}(\mathrm{Pt})$ - resents prejudice log tax / GDP;

$\mathrm{B}_{3}$ (Pti) - represents log profit tax / GDP;

$\mathrm{B}_{4}$ (VAT) - represents the log of value added tax / GDP;

$\mathrm{B}_{5}(\mathrm{Wt})$ - represents the log of withheld tax / GDP;

$\mathrm{B}_{6}(\mathrm{Ibt})$ - represents the log of individual businesses tax / GDP;

$\mathrm{B}_{7}(\mathrm{Idr} . .$.$) - represents \log$ tax of monthly statements and resource retention payment of taxes on interest, dividends, rent, win the lottery and gambling games/ GDP;

$\mathrm{B}_{8}(\mathrm{Ct})$ - represents a log of corporation tax / GDP;

$\mathrm{Ui}$ - represents a common error term.

Data for the the variables, Gdp, Pt, Pti, VAT, Wt, Ibt, Idr .., Ct are taken from the Central Bank of Kosovo, from the financial reports of the Ministry of Finance, and from the World Bank. The search was made in the period from 2007 to 2015. Given the limited access to data required for this model, data interpolation was made in certain time periods. In order for all variables to change in relative terms, they are introduced in the logarithm form. The model includes eight variables that are independent (exogenous) variables, while GDP is the dependent variable, a proxy variable for the economic growth of the economy. In the following tables we will specify the model as multiple and logarithmic regression as follows:

Table 2. The first model with 8 variables

\begin{tabular}{|c|c|c|c|c|c|c|}
\hline \multicolumn{7}{|c|}{.generate Ingdp $=\operatorname{In}(\operatorname{gdp})$} \\
\hline regress & Ip InCt In & Inl & InWt & InVAT & $\mathrm{InPt}$ & \\
\hline Source & Ss & $\mathrm{df}$ & & MS & & Number of obs \\
\hline Model & 190133037 & 7 & & .027161362 & & \\
\hline
\end{tabular}




\begin{tabular}{|c|c|c|c|c|c|}
\hline Residual & .000053739 & 1 & .000053739 & & $\mathrm{~F}(7,13)=$ \\
\hline Total & .190186776 & 8 & .023773347 & & $\begin{array}{l}505.44 \\
\text { Prob }>\mathrm{F} \\
0.0342 \\
\text { R-squared } \\
0.9997 \\
\text { Adj R-squared }= \\
0.9977 \\
\text { Root MSE } \\
.00733\end{array}$ \\
\hline Ingdp & Coef. & Std. Err. & $\mathrm{t}$ & $\mathrm{t}>\mathrm{ItI}$ & $\begin{array}{ll}95 \% & \text { conf. } \\
\text { interval] }\end{array}$ \\
\hline $\mathrm{InCt}$ & .35801133 & .1457588 & 2.46 & 0.246 & $\begin{array}{l}-1.494028 \\
2.210054\end{array}$ \\
\hline In Dtr.. & .120968 & .0208634 & 5.80 & 0.109 & $\begin{array}{l}-.1441112 \\
.3860792\end{array}$ \\
\hline In Ibt & 1.205135 & .5467891 & 2.20 & 0.271 & $\begin{array}{l}-5.7483421 \\
8.152748\end{array}$ \\
\hline Inwt & -.7758714 & .3704922 & -2.09 & 0.284 & $\begin{array}{l}-5.483421 \\
3.931678 \\
\end{array}$ \\
\hline InVAT & .4324824 & .1749389 & 2.47 & 0.245 & $\begin{array}{l}-1.790327 \\
2.655292 \\
\end{array}$ \\
\hline InIt & .5832352 & .1196127 & 4.88 & 0.129 & $\begin{array}{l}-.9365884 \\
2.103059 \\
\end{array}$ \\
\hline $\mathrm{InPt}$ & -.7479065 & .2080517 & -3.59 & 0.173 & $\begin{array}{l}-3.391454 \\
1.895641 \\
\end{array}$ \\
\hline cons & 2.556755 & .8641362 & 2.96 & 0.207 & $\begin{array}{l}-8.423136 \\
13.53665 \\
\end{array}$ \\
\hline
\end{tabular}

Source: STATA -13.

Table 3. The second model with 7 variables (without VAT)

\begin{tabular}{|c|c|c|c|c|c|}
\hline \multicolumn{6}{|c|}{$\begin{array}{l}. \text { generate Ingdp }=\operatorname{In}(\mathrm{gdp}) \\
\text {.regress Ingdp InCt InDtr. }\end{array}$} \\
\hline Source & ss & df & MS & & \multirow{4}{*}{$\begin{array}{l}\text { Number of obs }= \\
9 \\
\mathrm{~F}(6, \\
165.55 \\
\text { Prob }>\mathrm{F} \\
0.0060 \\
\text { R-squared } \\
0.9980 \\
\text { Adj R-squared }= \\
0.9920 \\
\text { Root MSE } \\
.01382\end{array}$} \\
\hline Model & .189804597 & 6 & .031634099 & & \\
\hline Residual & .0003821179 & 2 & .00019109 & & \\
\hline Total & .190186779 & 8 & .023773347 & & \\
\hline Ingdp & Coef. & Std. Err. & $\mathrm{t}$ & $\mathrm{t}>\mathrm{ItI}$ & $\begin{array}{l}{[95 \% \quad \text { conf. }} \\
\text { interval] }\end{array}$ \\
\hline $\mathrm{InCt}$ & .1076677 & .1976938 & 0.54 & 0.641 & -.7429399 \\
\hline
\end{tabular}




\begin{tabular}{|c|c|c|c|c|c|}
\hline & & & & & .9582754 \\
\hline In Dtr.. & .0858632 & .0288126 & 2.98 & 0.097 & $\begin{array}{l}-.0381072 \\
.2098336\end{array}$ \\
\hline In Ibt & 1.917674 & .8762045 & 2.19 & 0.160 & $\begin{array}{c}-1.85233 \\
5.687678\end{array}$ \\
\hline Inwt & -.7143319 & .6970578 & -1.02 & 0.413 & $\begin{array}{l}-3.713517 \\
2.284879\end{array}$ \\
\hline InIt & .5610205 & .2249163 & 2.49 & 0.130 & $\begin{array}{l}-.4067163 \\
1.528757 \\
\end{array}$ \\
\hline $\mathrm{InPt}$ & -.7245322 & .3919178 & -1.85 & 0.206 & $\begin{array}{l}-2.410819 \\
.9617541 \\
\end{array}$ \\
\hline cons & 2.711275 & 1.652234 & 1.67 & 0.237 & $\begin{array}{l}-4.28154 \\
9.704091 \\
\end{array}$ \\
\hline
\end{tabular}

Source: STATA -13.

\section{Discussion of Results}

$\mathrm{Y}(\mathrm{GDP})=(\mathrm{cons})+\beta_{1}(\mathrm{gdp})+\beta_{2}(\mathrm{pt})+\beta_{3}(\mathrm{It})+\beta_{4}(\mathrm{VAT})+\beta_{5}(\mathrm{wt})+\beta_{6}(\mathrm{Ibt})+\beta_{7}(\mathrm{Td}$.r. $)+\beta_{8}(\mathrm{ct})+\mu$ $\downarrow$

$\operatorname{Loggdp}=$ const $\alpha+\operatorname{lnPt} \beta_{2} \mathrm{x} 1+\ln I t \quad \beta_{3} \mathrm{x} 2+\ln \mathrm{VAT} \beta_{4} \mathrm{x} 3+\ln \mathrm{Wt} \quad \beta_{5} \mathrm{x} 4+\ln \mathrm{lbt} \beta_{6} \mathrm{x} 5+\ln \mathrm{Td} . \mathrm{r}$ $\beta_{7} \times 6+\operatorname{lnct} \beta_{8} \times 7+\mu$

$\downarrow$

Calculation of the coefficints in model (1) and interpretation of the results;

$\operatorname{Loggdp}=2.556($ const $)-0.747(\operatorname{lnPt})+0.583(\ln \mathrm{It})+0.432(\ln \mathrm{VAT})-0.775(\ln \mathrm{Wt})+$ $1.205(\ln I b t)+0.120(\operatorname{lnT} . d . r)+0.358(\operatorname{lnct})+0.864$

Table 4. The coefficient gained (variables)

\begin{tabular}{|l|l|l|l|l|l|l|l|l|}
\hline & const & $\operatorname{lnPt}$ & $\operatorname{lnIt}$ & $\operatorname{lnVAT}$ & $\ln w \mathrm{t}$ & $\operatorname{lnIbt}$ & LnTdr... & lnct \\
\hline $\mathrm{P}>\mathrm{t}$ & 0.207 & 0.173 & 0.129 & 0.245 & 0.284 & 0.271 & 0.109 & 0.246 \\
\hline $\mathrm{t})$ & 2.96 & -3.59 & 4.88 & 2.47 & -2.09 & 2.20 & 5.80 & 2.45 \\
\hline
\end{tabular}

Source: Database with STATA-13.

Based on the results obtained by calculating data with STATA-13, through the loglog model, the results obtained will be computed as follows (the results show the impact of taxes on the activity for economic development in conditions "ceteris paribus" represent only the impact of taxes (Pt, It, VAT, wtb, Ibt, Tdr.., ct) as independent variables, on GDP as the dependent variable.

Interpretation of $\mathrm{R} 2=0.999$ or $99.9 \%$, reflects that the determination coefficient is very high which means that the independent variables clarify $99.9 \%$ of the dependent variable.

$\checkmark \quad$ Referring to the results we see that probability $\mathrm{p}$ for significance level $5 \%$, alpha $(\alpha)$ interval of 0.05 , is higher that the value obtained from $p$ tables.

$\checkmark \quad$ Prob from tables $>\mathrm{F}=0.0342$ which means that with $34 \%$ probability we reject the research hypothesis $\mathrm{H} 0$. Therefore, taxes have negative effect on 
the economic growth affecting GDP negatively (decline). We accept the lternative hypothesis $\mathrm{H} 1$, stating that taxes have a positive effect on the economic growth affecting GDP positively (growth).

\section{Model 1:}

$L n Y=B 1+B 2 \ln X 1+B 3 \ln X 2+B 4 \ln X 3 B 5 \ln X 4+B 6 \ln X 5+B 7 \ln X 6+B 8 \ln X 7$ $+u i$

\section{Model 2:}

$L n Y=B 1+B 2 \ln X 1+B 3 \ln X 2+B 5 \ln X 4+B 6 \ln X 5+B 7 \ln X 6+B 8 \ln X 7+u i$

Calculation of coefficients in Model (1) and interpretation of the obtained results:

$\operatorname{Loggdp}=2.556($ const $)-0.747(\operatorname{lnpt})+0.583(\ln \mathrm{It})+0.432(\ln \mathrm{VAT})-0.775(\ln \mathrm{Wt})+$ $1.20(\operatorname{lnIbt})+0.120(\operatorname{lnT} \mathrm{dr} . .)+.0.358(\operatorname{lnct})+0.864$

$\checkmark$ Coefficient B1 $=$ Constant when X1 and X7 are zero;

$\checkmark$ Coefficient B2 $=-0.747$, indicates that an increase of $1 \%$ in personal tax will affect, on average, by $-0.747 \%$ GDP (decline under ceteris paribus conditions);

$\checkmark$ Coefficient B3 $=0.583$, indicates that an increase of $1 \%$ in earnings tax will have an average impact of $0.583 \%$ on GDP growth;

$\checkmark$ Coefficient B4 $=0.432$, indicates that an increase of $1 \%$ in Value Added Tax will have an average impact of $0.432 \%$ on GDP growth;

$\checkmark$ Coefficient B5 $=-0.775$, indicates that an increase of $1 \%$ in withheld tax will have an average impact of $-0.775 \%$ on GDP decline;

$\checkmark$ Coefficient B6 $=1.205$ indicates that an increase of $1 \%$ in individual business tax will have an average impact of $1.205 \%$ on GDP growth;

$\checkmark$ Coefficient $\mathrm{B} 7=0.120$ indicates that an increase of $1 \%$ in monthly tax collection of resources and payment of tax on interest, dividends, property rights, rent, lottery and gambling will have an average impact of $0.120 \%$ in GDP growth;

$\checkmark$ Coefficient B8 $=0.358$ indicates that an increase of $1 \%$ in corporate tax will have an average impact of $0.358 \%$ on GDP growth;

$\checkmark$ Empirical research results suggest that the impact of taxes has a major effect on GDP in the Republic of Kosovo. If all the coefficients are collected, we gain 1.17, which shows that economic growth in Kosovo has an increase over the average yield level because it is greater than 1. Based on the t-test, the coefficients are significant, except B2, and B5 and the unrelated variables affect the dependent variable with the following coefficients: $\mathrm{B} 2=$ $-0.747, \mathrm{~B} 3=0.583, \mathrm{~B} 4=0.432, \mathrm{~B} 5=-0.775, \mathrm{~B} 6=1.20, \mathrm{~B} 7=0.20, \mathrm{~B} 8=$ 0.358 .

Calculation of coefficients in Model (2) and interpretation of the obtained results:

Loggdp $=2.711($ const $)-0.724(\operatorname{lnPt})+0.561(\operatorname{lnIt})-0.714(\ln \mathrm{Wt})+1.917(\operatorname{lnIbt})$ $+0.085(\operatorname{lnT}$. d.r $)+0.107(\operatorname{lnct})+1.62$ 
$\checkmark \quad$ Coefficient B1 is constant when X1 and X6 are zero;

$\checkmark$ Coefficient B2 $=-0.724$, indicates that an increase of $1 \%$ in personal tax will have an average impact of $-0.724 \%$ on GDP reduction (under ceteris paribus conditions);

$\checkmark$ Coefficient B3 $=0.561$, shows that $1 \%$ increase in profit tax will have an average impact of $0.51 \%$ on GDP growth;

$\checkmark$ Coefficient B5 $=-0.714$, indicates that $1 \%$ increase in withheld tax will have an average impact of $-0.714 \%$ on GDP reduction;

$\checkmark$ Coefficient B6 $=1.917$ indicates that an increase of $1 \%$ in individual business tax will have an average impact of $1.917 \%$ on GDP growth;

$\checkmark$ Coefficient B7 $=0.085$ indicates that $1 \%$ increase in monthly tax revenue from the resources and payments of taxes on interest, dividends, property rights, leases, lottery winnings and gambling will have an average impact of $0.085 \%$ on GDP growth;

$\checkmark$ Coefficient B8 $=0.107$, indicates that $1 \%$ increase in corporate tax will have an average impact of $0.107 \%$ on GDP growth.

Based on the t-test, the coefficients are significant, except B2 and B8, and the unrelated variables affect the dependent variable with the following coefficients: B3 $=0.561, \mathrm{~B} 5=-0.714, \mathrm{~B} 6=1.917, \mathrm{~B} 7=0.085$.

Which of the two accrual models is best suited for approximating the data from the Tables above? Through the F-test formula we ascertain the common significance of the evaluation coefficients in the econometric models. This test is also used if we want to ascertain whether any of the variables should remain or be extracted from the model.

$$
\begin{aligned}
& F==\frac{E S S /(k-1)}{R S S /(n-k)}=\frac{0.1900133037 /(8-1) 0.027144746}{\frac{0.00005579}{9-8} 0.00005379}=505.54 \\
& F=\frac{\left(R S S_{R}-R S S_{U R}\right) / m}{R S S_{U R} /(n-k)}=\frac{0.0000382179-0.000053739 / 1}{0.000053739 / 1}=6.11
\end{aligned}
$$

If the value obtained from the F-test is greater than the critical value then the zero hypotheses is dropped, which considers that the variation in the model is insignificant and an alternative hypothesis is accepted which finds that the VAT variable should remain in the model.

From the F-test which indicates the general specification of the model, based on these facts we will solve it as a linear model, since the F-test is higher than the value from the F-table respectively $(505>6.11)$. While the value of F-statistics is greater 
than the critical value, we conclude that zero hypothesis is rejected therefore we accept the alternative hypothesis, with the variable of the VAT in it.

\section{Conclusions}

This research contributes to fiscal policy to create a tax structure that will be compatible with the level of economic development, having positive effects on revenues, investments, employment and economic growth. The results of this study show that not all taxes have a positive impact on its economic growth.

Based on the analysis of the selective taxes included in this study, it is concluded that tax on profits, tax on individual business, value added tax, taxation of monthly statements, collection of resources and payment of taxes on interest, dividends, property rights, rentals, lottery and gambling winnings and corporation tax are significant and have a positive impact on Kosovo's GDP, unlike tax personal and withholding tax which are not significant and have a negative impact on economic growth.

From the data processed with STATA-13, through the log-log model, the analyzed coefficients indicate high degree of determination. From the interpretation of R2 being 0.999 it reflects a high determinant coefficient of $99.9 \%$, which means that the independent variable clarifies $99.9 \%$ the subordinate variable.

Also, changes in the structure of the tax system and in the level of revenues can influence the economic activity, but not all tax changes have equivalent or even positive, effects on long-term growth. The higher rates may be more distortionary and hence a negative impact growth while lower rates may generate revenues that are spent in productive ways. Also, by lowering tax rates, extending the tax basis, reducing tax exemptions and building such a tax structure can afecct positively the economic growth and the economic development of Kosovo.

\section{References:}

Anastassiou, Th., Drirsaki, Ch. 2005. Tax Revenues and Economic Growth: An Empirical Investigation for Greece Using Causality Analysis. Journal of Social Sciences, 1(2), 99-104.

Arnold, J. 2008. Do Tax Structures Affect Agregate Economic Growth? Empirical Evidence form Panel of OECD countries.

Assessment of Public Financial Management, Public expenditure and Financial Accountability (PEFA). 2008. The Ministry of Finance of Kosovo. World Bank.

Asllani, G., Statovci, B. 2018. Effect of the Change in Value Added Tax on the Fiscal Stability of Kosovo. Croatian Economic Association Zagreb, 65(6), 513-540.

Asllani, G. 2012. The impact of fiscal policy on economic development. OEconomica, Danubius University of Galati, 1(1), 123-137.

Barbara, J. 1997. Public Finance, Informtor, Zagreb, Croatia.

Barro, R. 1990. Government expenditures in a simple endogenous growth model OECD, reports for tax revenues. 
Desislava, S. 2017. Tax Structure and Economic Growth: Evidence from the European Union. Contaduria Y Administracion, 62(3),1041-1057.

Daniel, B., Jeffrey, P. 2013. Investment Taxation and Portfolio Performance. Journal of Public Economics, 97(1), 245-257.

Feld, L., Heckemeyer, J. 2008. FDI and Taxes: A Meta-study. ZEW. Working Paper Nr 08128.

Feld, L.P. 2005. Tax comptition: How great is the challenge? Croatian Economic Association Zagreb, 56(9), 723-758.

Frede, E., Dahlyb, B. 2012. The Impact of Tax Cat on Economic Growth: Evidence Form Canadian Province. National Tax Journal, 65(3), 563-594.

Gallagher, M., Babič, A. 2005.Tax Simplification for Jobs and Growth, Croatia.

Gasteratos, I., Karamalis, M. and Koutoupis, A. 2016. Shadow Economy Worsens Income distribution. International Journal of Economics \& Business Administration, 4(3), 80-92.

Gerson, P. 1998. The impact of fiscal policy variables on output growth, IMF-WP.

Genser, B. 2006. The Dual Income Tax: Implementation and Experience in European Countries. Croatian Economic Association Zagreb, 57(3-4), 271-288.

Judd, K. 1985. Restributive Tax on a simple perfect forward pattern, Journal for Economic Policy, 28(1), 59-83.

Jurkovič, P. 1991. Designing a tax system to promote structural change. The role of tax reforme in Central and Eastern European Economies, OECD.

Kesner-Škreb, M. 1999. Tax Policy and Economic Growth. Croatian Economic Survery, 73, 62-121.

Kneller, R., Bleaney, M., Gemmell, N. 1999. Fiscal Policy and Growth. Evidence fom OECD, 74(2), 171-190.

Komoni, S. 2008. Public Finance. Pristine, National Library of Kosovo.

Nechaev, A., Antipina, O. 2016. Analysis of the Impact of Taxation of Business Entities on the Innovative Development of the Country. European Research Studies Journal, 19(1), 71-83.

Peci, B. 2018. Publice Finance. University of Pristina, National Library of Kosovo.

Rimmler, M., Rose, M., Zöller, D. 2017. Tax Reform for Tax Competition: Which Alternatives should be Used? Croatian Economic Association Zagreb, 56(11), 1079-1100.

Romero, D., Strauch, R. 2008. Publice Finance on long-term growth in Europe: Evidence from panel data analysis. Europen Journal of Political Economy, 24, 172-191.

Solow, R. 1956. On contribution for economic growth. Quartely Journal of Economics, 70(1), 65-94.

Schraztenstaller, W., Kohler, T. 2015. The Impact of Tax on Economic Growth. Case Study of OECD Countries.

Taxation Trends Report in the European Union. 2012.

Vito, T. 1990. Tax structure and growth: are some taxes better than others? Public choise. Working paper, IMF.

Widmalm, F. 1999. Tax structure and growth. Are some tax better than other? Public choice, Working paper 107, IMF.

World Bank. 2009. A handbook for Tax Simplification. Working paper, Washington DC.

William, G., Andrew, A. 2017. Effects of Income Tax Changes on Economic Growth. Economics of Tax Policy, 13-39. 